\title{
Molecular purging of multiple myeloma cells by ex-vivo culture and retroviral transduction of mobilized-blood CD34+ cells
}

\author{
Sara Deola*1,4, Samantha Scaramuzza1, Roberto Sciarretta Birolo1, \\ Massimiliano Cergnul ${ }^{2}$, Francesca Ficara ${ }^{1}$, Jonathan Dando1, \\ Claudia Voena ${ }^{2,5}$, Sergio Vai ${ }^{2}$, Marta Monari ${ }^{2}$, Enrico Pogliani ${ }^{3}$, \\ Gianmarco Corneo ${ }^{3}$, Jacopo Peccatori², Silvia Selleri ${ }^{4,6}$, Claudio Bordignon ${ }^{2}$, \\ Maria Grazia Roncarolo ${ }^{1}$, Alessandro Aiuti ${ }^{1}$ and Marco Bregni ${ }^{2}$
}

\begin{abstract}
Address: ${ }^{1}$ San Raffaele Telethon Institute for Gene Therapy (HSR-TIGET), Scientific Institute H.S. Raffaele, Milan, Italy, ${ }^{2} \mathrm{Hematology}$ and BMT Unit, Scientific Institute H.S. Raffaele, Milan, Italy, ${ }^{3}$ Hematology and Bone Marrow Transplant Unit, Hospital S. Gerardo, Monza, Italy, ${ }^{4}$ Department of Transfusion Medicine, Clinical Center, National Institutes of Health, Bethesda, MD 20892, USA, ${ }^{5}$ Department of Biomedical Sciences and Human Oncology and Center for Experimental Research and Clinical Studies, University of Turin, Turin, Italy and ${ }^{6}$ Department of Human Morphology, University of Milan, Milan, Italy

Email: Sara Deola* - deola.sara@hsr.it; Samantha Scaramuzza - scaramuzza.samantha@hsr.it; Roberto Sciarretta Birolo - roberto.sciarretta@molmed.it; Massimiliano Cergnul - maxcergnul@yahoo.it;

Francesca Ficara - fficara@stanford.edu; Jonathan Dando - jonathan.dando@spr-r.it; Claudia Voena - clavoe@katamail.com; Sergio Vai - vai.sergio@libero.it; Marta Monari - monari.marta@hsr.it; Enrico Pogliani - enrico.pogliani@unimib.it;

Gianmarco Corneo - gianmarco.corneo@unimib.it; Jacopo Peccatori - peccatori.jacopo@hsr.it; Silvia Selleri - selleris@mail.nih.gov;

Claudio Bordignon - bordignon.claudio@hsr.it; Maria Grazia Roncarolo - roncarolo.mariagrazia@hsr.it;

Alessandro Aiuti - aiuti.alessandro@hsr.it; Marco Bregni - bregni.marco@hsr.it

* Corresponding author
\end{abstract}

Published: 12 July 2007

Journal of Translational Medicine 2007, 5:35 doi:10.1 186/1479-5876-5-35
Received: 27 June 2007

Accepted: 12 July 2007

This article is available from: http://www.translational-medicine.com/content/5/I/35

(C) 2007 Deola et al; licensee BioMed Central Ltd.

This is an Open Access article distributed under the terms of the Creative Commons Attribution License (http://creativecommons.org/licenses/by/2.0), which permits unrestricted use, distribution, and reproduction in any medium, provided the original work is properly cited.

\begin{abstract}
Background: Tumor cell contamination of the apheresis in multiple myeloma is likely to affect disease-free and overall survival after autografting.

Objective: To purge myeloma aphereses from tumor contaminants with a novel culture-based purging method.

Methods: We cultured myeloma-positive $\mathrm{CD} 34^{+} \mathrm{PB}$ samples in conditions that retained multipotency of hematopoietic stem cells, but were unfavourable to survival of plasma cells. Moreover, we exploited the resistance of myeloma plasma cells to retroviral transduction by targeting the hematopoietic $\mathrm{CD} 34^{+}$cell population with a retroviral vector carrying a selectable marker (the truncated form of the human receptor for nerve growth factor, $\triangle$ NGFR). We performed therefore a further myeloma purging step by selecting the transduced cells at the end of the culture.

Results: Overall recovery of CD34+ cells after culture was $128.5 \%$; $\triangle$ NGFR transduction rate was $28.8 \%$ for $\mathrm{CD} 34^{+}$cells and $0 \%$ for CDI38-selected primary myeloma cells, respectively. Recovery of $\mathrm{CD}^{2} 4^{+}$cells after $\triangle$ NGFR selection was $22.3 \%$. By patient-specific lg-gene rearrangements, we assessed a decrease of 0.7-l.4 logs in tumor load after the CD34+ cell selection, and up to 2.3 logs after culture and $\triangle$ NGFR selection.

Conclusion: We conclude that ex-vivo culture and retroviral-mediated transduction of myeloma leukaphereses provide an efficient tumor cell purging.
\end{abstract}




\section{Background}

The standard therapy for multiple myeloma is high-dose chemotherapy with autologous reinfusion of hematopoietic stem cells [1-3]. Molecular evidences indicate that residual cancer cells contaminate the transplant, and several reports estimate a tumor burden of $10^{4}-10^{9}$ plasma cells per transplant $[4,5]$. Although their role in determining patients' overall survival is still unclear, a correlation has been shown between a plasma cell contamination $>2$ $\times 10^{5} /$ lt and an early relapse $[6,7]$. In an effort to overcome this problem, a purging approach of aphereses was developed with a positive selection of $\mathrm{CD} 34^{+}$cells, but no significant clinical advantage was achieved with this method [8]. Recent studies show that $75 \%$ of aphereses are still contaminated with plasma cells after the CD34+ selection [9]. Other purging approaches exploited a more restricted phenotypic selection to eliminate tumor contaminants, such as CD34+/lin-/Thy $1^{+}[10,11]$, or combined selections (CD34+CD19-) [12]. For both methods, preliminary clinical results indicate good purging achievements, but high infection rates, and poor bone marrow reconstitution results, due to the effects of progenitor- and T-cells depletion [11]. Barbui et al. described a purging approach based on negative selection of mobilized blood stem cells [13], in which they achieve safe engraftment results with purged cell grafts, but without advantages in the overall survival of patients. A wide variability of purging results - ranging from 0 to 7 logs depletions - is achieved by these phenotype-based purging methods. Still no clinical trial so far established a defined threshold of purging necessary to reduce the risk of relapse while maintaining a safe clinical feasibility.

We investigated the efficiency of a culture-based purging of myeloma aphereses.

Myeloma plasma cells exhibit a high mortality in culture (50-95\% in 9 days) [14]; we exploited this biological behaviour to perform a culture-based purging of myeloma CD34-selected leukaphereses. We designed a 4-day cytokine-culture procedure, adequate for a safe maintenance of the $\mathrm{CD} 34^{+}$cell multilineage phenotype, but unfavourable to plasma cells. Moreover myeloma cells display a very low retroviral-mediated transduction rate, even after repeated infection cycles (1.5-5.4\%) [14,15], therefore we structured the protocol to allow the insertion and the expression of retroviral genes in the CD34+cells. Through this approach, we directed the selectable marker $\triangle$ NGFR to the CD $34^{+}$cell population, adding a further purging possibility. $\triangle$ NGFR has already been utilized in $\mathrm{T}$ cell populations to control GvHD in allogeneic bone marrow transplants $[16,17]$. To assess the effectiveness of purging, we amplified patient-specific, clonal tumor immunoglobulin heavy-chain $(\mathrm{IgH})$ rearrangements before and after $\mathrm{CD} 34^{+}$cell culture procedure and retroviral transduction.

We present here the results of culture and transduction of primary cells from leukaphereses of 19 multiple myeloma (MM) patients, undergoing high-dose chemotherapy and peripheral blood cell autografting.

\section{Methods \\ Cell processing}

Mobilized peripheral blood (MPB) and bone marrow (BM) cells were collected from MM patients enrolled in high-dose chemotherapy programs, approved by IRB at HSR, after informed consent. Mononuclear cells were purified by density centrifugation using the lymphocyte separation medium Lymphoprep (Nycomed Pharma, Asker, Norway).

CD $34^{+}$cells were positively selected using the following immunomagnetic separation devices: mini-, and midiMACS (CD34+ MultiSort Kit, Miltenyi Biotec, Bergisch Gladbach, Germany), cliniMACS (Miltenyi Biotec), ISOLEX300i (Baxter Healthcare, Irvine, CA, USA), according to the manufacturer's instructions. $\mathrm{CD} 138^{+}$cells were selected with mini-MACS device, using direct conjugated anti CD138 microbeads (Miltenyi Biotec). Immunoselected cells were analyzed by flow-cytometry, to determine the purity of selections.

\section{Retroviral supernatant production}

BML-1 Moloney Murine Leukemia Virus (MoMLV) based retrovirus, containing the $\triangle$ NGFR marker gene under the control of LTR promoter [18] was collected from producer cells, kindly provided by Roche Diagnostics GmbH. Producer cells were expanded in $200 \mu \mathrm{l} / \mathrm{cm}^{2}$ Iscove's modified Dulbecco's medium (IMDM, Bio Whittaker, Verviers, Belgium) supplemented with $10 \%$ fetal bovine serum (FCS, Euroclone, Wetherby, West Yorkshire, UK), $100 \mathrm{U} / \mathrm{ml}$ penicillin-streptomycin, and $2 \mathrm{mM} \mathrm{L}$-glutamine at $5 \times 10^{4}$ cells $/ \mathrm{cm}^{2}$, at $37^{\circ} \mathrm{C}$ with $5 \% \mathrm{CO}_{2}$. The medium was replaced after 48 hours, 72 hours and 84 hours reducing the volume to $66 \mu \mathrm{l} / \mathrm{cm}^{2}$ and the temperature to $33^{\circ} \mathrm{C}$ [19]. Viral supernatant (SN) was collected with 12-hours serial collections, 0.45 filtered and $-80^{\circ} \mathrm{C}$ frozen before use.

\section{Culture, transduction and selection of transduced cells}

$\mathrm{CD} 34^{+}$cells were cultured in X-Vivo 10 (Bio Whittaker) serum free medium containing the cytokines thrombopoietin (PeproTech, Rocky Hill, NJ, USA), FLT3-Iigand (PeproTech), stem cell factor (R\&D Systems Minneapolis, $\mathrm{MN}$, USA) at $50 \mathrm{ng} / \mathrm{ml}$ (thereafter designated complete medium) at $5-6 \times 10^{5} \mathrm{cells} / \mathrm{cm}^{2}$ for 84 hours. Transduction of $\mathrm{CD} 34^{+}$cells were performed in complete medium, at the same cell concentration. Cells were prestimulated 
for 24 hours, and overnight transduced with the BML-1 retroviral vector on RetroNectin (TaKara Biomedicals, Kyoto, Japan)-coated non-tissue culture-treated plates, or T75 flasks, with $4: 1 \mathrm{v} / \mathrm{v}$ SN/culture medium, supplemented with $5 \times$ concentrated cytokines. Fresh complete medium was replaced after virus withdrawal and cells were cultured for further 48 hours. At the end of the culture, cells were collected, washed, and incubated with anti-NGFR biotinylated antibody at $2.5 \times 10^{6} \mathrm{cell} / \mathrm{ml}$ for 30 minutes at $4{ }^{\circ} \mathrm{C}$ and then with $10 \mu \mathrm{l}$ streptavidin (SA)conjugated microbeads (Miltenyi Biotec) for 15 minutes at $4^{\circ} \mathrm{C} . \triangle \mathrm{NGFR}^{+}$cells were then isolated by mini-MACS immunoselection device. $\triangle$ NGFR positive and negative fractions were analyzed by flow-cytometry for CD34, CD45, CD138, and $\triangle$ NGFR antigens. Clonal transduction of $\mathrm{CD}_{138^{+}}$cells was performed in U-bottom 96-well plates with 4:1 SN/culture medium only in wells scored positive for 1 cell at light microscope. Prestimulation was performed with $40 \mu \mathrm{l}$ of complete medium, and after 24 hours, $128 \mu \mathrm{l}$ of virus, complemented with $32 \mu \mathrm{l}$ of $5 \times$ cytokines, were directly added to each well. To avoid disturbance of the cells, transduction was stopped by substituting $150 \mu \mathrm{l}$ of medium with fresh complete medium. Doubling of single cells was scored daily by microscopy and viability of cells using Trypan blue exclusion assessed at the end of transduction.

\section{Immunofluorescence staining and flow cytometric analyses}

Cells were stained with conjugated monoclonal antibodies (mAbs) in $100 \mu \mathrm{l}$ PBS, 0,1\% sodium-azide, 0,3\% BSA (PBS FACS) at $4{ }^{\circ} \mathrm{C}$ for 25 minutes, after the staining cells were washed and resuspended in PBS FACS. For biotinylated mAbs a secondary staining with streptavidin-PE/ FITC was performed. The following mAbs were used: CD34-PE (Becton Dickinson, San Josè, California, USA), CD45-FITC/TC (Caltag, Burlingame, California, USA), CD138-FITC (Valter Occhiena, Torino, Italy), CD38-TC (Caltag), SA-FITC/PE/TC (Caltag), biotinylated-NGFR. Isotype-identical mAbs IgG1-FITC/PE/TC and biotinylated-IgG1 (Caltag) served as control. Samples were acquired with FacsScan device (Becton Dickinson). Data were analyzed using CellQuest software (Becton Dickinson).

\section{In vitro clonogenic cell assays}

Long-term marrow cultures (LTMC) were performed according to a described procedure [20]. Briefly, 70000 $\mathrm{CD}^{2}{ }^{+} / \Delta \mathrm{NGFR}^{+}$cells were seeded on top of MS5 murine stromal cells in Myelocult medium (StemCell Technologies, Vancouver, BC, CA), added with $10 \mathrm{ng} / \mathrm{ml}$ IL6 (Pepro Tech) and half of the medium was weekly replaced. After three weeks of culture, cells were resuspended in Methocult GF medium (StemCell Technologies) and plated in duplicate in a (Colony Forming Units-Cells) CFU-C assay.
Colonies were scored two weeks later, individually picked and DNA was extracted for PCR analysis. DNA extraction was performed adding, for each colony, $25 \mu \mathrm{l}$ of $\mathrm{KCl}$ lysis buffer and protease $\mathrm{K}$ at $50 \mu \mathrm{g} / \mathrm{ml}$. Colonies were incubated overnight at $37^{\circ} \mathrm{C}$ and heat inactivated for $15^{\prime}$ at $94^{\circ} \mathrm{C}$. KCl lysis buffer consists of $1: 1 \mathrm{v} / \mathrm{v}$ mix of solution A (100 mM KCl, $10 \mathrm{mM}$ Tris pH 8.3, $\left.2.5 \mathrm{mM} \mathrm{MgCl}_{2}\right)$ and solution $\mathrm{B}\left(10 \mathrm{mM}\right.$ Tris $\mathrm{pH} 8.3,2.5 \mathrm{mM} \mathrm{MgCl}_{2}, 1 \%$ Tween-20, 1\% NP-40). DNA was then analyzed for the presence of $\triangle$ NGFR transgene, and patient-specific myeloma markers.

\section{PCR assays}

To determine the presence of $\triangle$ NGFR transgene, DNA was amplified with primers 5'-L $\Delta 1$ : GGCCGTTGGATTACACGGTC and 3'-MAGO: CCTACAGGTGGGGTCTTTCA. PCR reactions were carried out in a final volume of $25 \mu \mathrm{l}$,

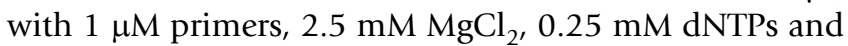
1.25 U Taq Gold (Perkin Elmer, Wellesley, MA, USA), at following conditions: 7 minutes at $94^{\circ} \mathrm{C}, 50$ seconds at $94^{\circ} \mathrm{C}, 50$ seconds at $60^{\circ} \mathrm{C}$ and 50 seconds at $72^{\circ} \mathrm{C}$ for 40 cycles, 5 minutes at $72^{\circ} \mathrm{C}$. As a control for the presence of DNA, HLA genes were amplified (primer 5':GTGCTGCAGGTGTAAACTTGTACCAG and primer 3':CACGGATCCGGTAGCAGCGGTAGAGTTG). PCR conditions were the same as above, except for annealing temperature that was $56^{\circ} \mathrm{C}$.

To detect tumor cells, the clonal variable region (VDJ) rearrangements of the $\mathrm{IgH}$ genes of each patient were amplified using 5 ' consensus primers derived from the conserved sequences of the variable region and 3 ' consensus primer derived from the joining region as previously described [21]. PCR products were sequenced and sequences from CDR2 and CDR3 regions were used to design patient-specific tumor primers. Oligonucleotides were subsequently tested for specificity using polyclonal DNA from normal individuals as negative controls. For each patient, $\mathrm{CD} 34^{+}$cells before and after culture, and after $\triangle$ NGFR immunoselection were amplified to detect residual myeloma cells. Cells were directly resuspended at $1 \times 10^{5} / 50 \mu \mathrm{l}$ in $\mathrm{KCl}$ lysis solution for genomic DNA extraction (as described above) and PCR amplifications were performed using 5, or $10 \mu \mathrm{l}$ of DNA. A first round PCR was performed using patient specific VH family primers and a second round was performed amplifying $1 \mu \mathrm{l}$ of the first PCR product with patient-specific primers. The sensitivity was $10^{-4}-10^{-5}$ [21].

Limiting dilution assays were performed serially diluting DNA with water, in 0.5 log increments and each dilution was subsequently amplified with patient-specific primers. At least five PCR reactions were performed for each dilution level from the level in which reactions were positive up to the level in which all reactions were negative for 
clonal markers. Polyclonal DNA was always included as negative control. This technique has been previously validated by diluting a known number of tumor cells in normal marrow or peripheral blood cells. An indirect quantification of the tumor load in the positive samples of the dilution was performed according to the statistical methods of likelihood maximization and $\chi^{2}$ minimization (MC), derived from the single-hit Poisson model, as described by Taswell [22]. Combined frequency estimates were obtained by analyzing with MC estimator the pooled frequency determinations. Comparison of frequencies between groups was performed through evaluation of confidence interval (CI) and probability value, and CI for the ratio of 2 frequencies. All calculations were performed using MATLAB (version 5, The Math Works Inc.).

\section{Results Culture of myeloma aphereses, transduction and selection procedures}

Nineteen MPB leukaphereses products were CD34selected by miniMACS $(n=15)$, midiMACS $(n=1)$, cliniMACS $(\mathrm{n}=1)$ or ISOLEX immunoselection system $(\mathrm{n}=$ 2). Mean purity of CD34+ cells was $80.6 \pm 19 \%$ (Table 1 ). CD $34^{+}$cells were cultured for 84 hours, in complete medium. We previously described that this protocol allows a safe expansion of multipotent progenitors, without impairing their reconstitution capacity in severe combined immunodeficiency-humanized (SCID-hu) mice [18]. A portion of the CD34+ cells was exposed to a retroviral transduction: after 24 hours of culture with complete medium, cells were overnight transduced with a MoMLVderived retroviral vector, carrying the $\triangle$ NGFR gene [17]. After transduction, viral supernatant was replaced with fresh complete medium, and cells were allowed to express the transgene for further 48 hours (total culture time 84 hours, as in the non-retroviral exposed cytokine-culture). Transduced cells were immunoselected by $\Delta$ NGFR expression with MACS immunoselection system (Figure 1A), as previously described [23]. Mean CD $34^{+}$cells transduction rate was $28.9 \pm 12 \%$, and purity of $\triangle$ NGFR immunoselected CD $34^{+}$cells was $92.5 \pm 5 \%$.

At the end of the procedure, $67.7 \pm 13 \%$ of $\triangle \mathrm{NGFR}$ selected cells still retained the CD34 phenotype, indicating a recovery of $22.3 \pm 15 \%$ of the initial $\mathrm{CD} 34^{+}$cell number (Table 1).

We did not observe differences in results when we performed the procedure with high numbers of CD34+ cells (Table 1: exp. MM12, and MM14).

Mean fold-expansion of cytokine-cultured cells was 1.4, and CD34+ cells after culture were $128.5 \%$ of the initial number. $\mathrm{CD}_{34}{ }^{+}$antigen expression was $91.8 \pm 4 \%$ after cytokine culture, and $67,7 \pm 13 \%$ after transduction and selection of $\triangle \mathrm{LNGFR}^{+}$cells. Recovery of total cells and CD34+ cells in a representative experiment is shown in Figure 1B.

\section{Molecular purging}

To assess the results of myeloma-cell purging, we developed patient-specific primers for tumor-specific monoclonal immunoglobulin gene rearrangements in 9 patients (MM\#3,6,10/14,12,13,15,16,18 and 19). We amplified by PCR complementary determining regions I and III of the heavy chain VDJ immunoglobulin fragments, and we monitored monoclonal residual rearrangements in the apheresis product, after CD $34^{+}$selection, after culture and after transduction. Mononuclear cells, CD34+ fresh cells, cytokines-cultured cells, and $\triangle$ LNGFRpositive and -negative selected fractions were analyzed in 10 experiments, and DNA was amplified for myeloma specific clonal rearrangements.

Undiluted DNA was first amplified in 5 PCR reactions for each patient. Only in samples where sufficient material was available $(n=6)$, serial $0.5 \log$ dilutions of DNA were performed before amplification, to allow a quantification of the purging. Results of the amplifications were interpreted with a Poisson estimate [22]. Since no quantitative real-time PCR has been performed, the results should be taken in relative terms (logdecreaseoftheinitialcell frequency). When we amplified DNA from mobilized aphereses, $83.3 \%$ of samples showed detectable myeloma contaminants, and $77.8 \%$ of the samples still retained myeloma cells after CD34+ antigen selection (Table 2, gray shaded cells). The amount of tumor decrease after this first purging-step ranged from $<0.67$ to 1.36 logs. After $e x$ vivo cytokine culture, $57.1 \%$ (4 out of 7 ) tumor-positive CD34+ samples lost myeloma specific rearrangements $(\mathrm{MM}, 14,18,19)$, with an estimation of 0 to $>2.35$ logs purging, with respect to the initial tumor load. We then measured how cell exposure to retroviral vector, and selection of transgene-expressing cells contributed to the purging. All the samples purged after cytokines-culture were also PCR negative for myeloma specific rearrangements after transduction and selection of the $\triangle \mathrm{NGFR}^{+}$cell fraction. Among the $3 \Delta \mathrm{NGFR}^{+}$selected samples still positive for myeloma specific rearrangements, we observed a further decrease of myeloma contamination in samples MM15 and MM16 (range of purging: 0-5 to $1 \mathrm{log}$ ). Comparing the frequencies of tumor load in the different pooled data, we found a strong statistical significance between fresh CD34+ cells vs. CD34+ cells after culture, and after $\triangle$ NGFR selection (Table 3 ). When we compared the purging results of the culture with the $\triangle \mathrm{NGFR}^{+}$cell fraction, we failed to find a relevant statistical significance $(p>0.1)$. This result suggests that the culture itself plays a major role in the purging. 
Table I: Results of CD34+ cell selection, culture and transduction

\begin{tabular}{|c|c|c|c|c|c|c|c|}
\hline Patient & $\begin{array}{l}\text { Number of CD34+ } \\
\text { selected cells }\left(\times \mid 0^{3}\right)\end{array}$ & $\begin{array}{l}\text { Purity of CD34+ } \\
\text { selected cells (\%) }\end{array}$ & Transduction (\%) & $\begin{array}{l}\text { Number of } \\
\Delta \text { LNGFR selected } \\
\text { cells }\left(\times 10^{3}\right)\end{array}$ & $\begin{array}{l}\text { Purity of } \\
\Delta \text { LNGFR } \\
\text { selected cells (\%) }\end{array}$ & $\begin{array}{l}\% \text { CD } 34^{+} \text {cells } \\
\text { among } \Delta \text { LNGFR } \\
\text { selected cells }\end{array}$ & $\begin{array}{l}\text { CD34+ } \\
\text { transduced cells } \\
\text { vs initial CD34 } \\
\text { cells (ratio) }\end{array}$ \\
\hline MM I & 1082.0 & 78.6 & 29.8 & 156.2 & 92.8 & 72.4 & 13.3 \\
\hline MM 2 & 1913.0 & 33.6 & 20.9 & 36.0 & 85.5 & 43.6 & 24.4 \\
\hline MM 3 & 887.0 & 87.3 & 32.4 & 456.0 & 93.2 & 60.2 & 35.4 \\
\hline MM 4 & 1239.0 & 91.2 & 26.7 & 394.6 & 96.9 & 45.1 & 15.8 \\
\hline MM 5 & 1229.0 & 95.8 & 20.1 & 238.6 & 85.4 & 62.4 & 12.7 \\
\hline MM 6 & 1576.0 & 80.6 & 32.1 & 1520.0 & 94.5 & 62.2 & 74.4 \\
\hline MM 7 & 4285.0 & 37.1 & 31.4 & 729.0 & 90.4 & 67.6 & 31.0 \\
\hline MM 8 & 341.0 & 96.8 & 8.5 & 96.4 & 91.7 & 79.7 & 23.3 \\
\hline MM 9 & 1000.0 & 86.1 & 38.5 & 490.0 & 89.3 & 68.5 & 39.0 \\
\hline MM 10* & 1000.0 & 97.2 & 56.1 & 266.0 & 89.3 & 78.2 & 21.4 \\
\hline MM II & 500.0 & 77.6 & 33.7 & 78.0 & 77.9 & 75.0 & 15.1 \\
\hline MM 12 & 15000.0 & 97.2 & 17.0 & 3900.0 & 88.0 & 76.3 & 20.4 \\
\hline MM I3 & 1000.0 & 50.4 & 26.0 & 175.0 & 95.0 & 71.0 & 24.7 \\
\hline MM I4* & 22300.0 & 98.0 & 56.2 & 7990.0 & 97.8 & 67.5 & 24.1 \\
\hline MM I5 & 4400.0 & 76.0 & 18.0 & 576.0 & 93.3 & 79.0 & 13.8 \\
\hline MM I6 & 2890.0 & 79.0 & 20.0 & 396.0 & 97.3 & 84.0 & 14.6 \\
\hline MM 17 & 900.0 & 95.0 & 28.5 & 148.0 & 97.4 & 66.0 & 11.4 \\
\hline MM 18 & 1740.0 & 78.4 & 26.0 & 234.0 & 95.4 & 38.4 & 6.6 \\
\hline MM 19 & 2890.0 & 78.0 & 30.0 & 560.0 & 99.8 & 67.9 & 16.9 \\
\hline MM 20 & 2100.0 & 98.7 & 26.5 & 170.0 & 98.8 & 89.8 & 7.4 \\
\hline $\begin{array}{l}\text { Mean } \pm \\
S D\end{array}$ & & $80.6 \pm 19 \%$ & $28.9 \pm 12 \%$ & & $92.5 \pm 5 \%$ & $67.7 \pm 13 \%$ & $22.3 \pm 15 \%$ \\
\hline
\end{tabular}

$\mathrm{CD} 34^{+}$enriched cells of 19 patients were transduced with the $\triangle$ LNGFR retroviral vector, selected for transgene after 48 hours, and analyzed by flow cytometry. The last column shows the ratio between the number of $\mathrm{CD} 34^{+}$cells in the $\triangle \mathrm{NGFR}^{+}$selected cell population, and the initial number of $\mathrm{CD} 34^{+}$cells. * cells derived from the same patient.

Multiple myeloma cells: transduction and division pattern To assess the transduction rate of myeloma cells, we infected $\mathrm{BM} \mathrm{CD} 34^{+}$cells of a MM patient, after adding back to the cell population CD138+ myeloma plasma cells sorted from the same patient (ratio 1:1). By this way we reproduced our experimental condition setting, which includes a mixed population of healthy CD34+ cells and myeloma cells. In addition, in a parallel experiment, we transduced CD $138^{+}$sorted cells at $1 \times 10^{6} /$ well, to assess the transduction rate on a consistent number of cells, and at 1 cell/well, to study the division rate of tumor cells during transduction and therefore the possibility of the single cell to be infected by retroviral vectors (Figure 2).

Clonal transduction was performed at the same concentration of cytokines and virus as in the standard cell transduction, and the division pattern scored during the culture by light microscope ( $\mathrm{n}=89$ single-cell wells). At the end of procedure we stained each well with Trypanblue dye, to assess the viability of the cells. Whereas transduction rate of $\mathrm{CD}^{2} 4^{+}$cells was $21.4 \%$ in the mixed cell population, no $\mathrm{CD} 138^{+}$cell was transduced, neither in this cell population, nor in the CD $138^{+}$selected cells. The rate of $\mathrm{CD} 138^{+}$clonal cell division during viral exposition was $3.7 \%$, but all cells died before the end of procedure, as assessed by Trypan blue labelling.

Previous studies report that LTMC can sustain myeloma cells [20]. To exclude the presence of myeloma "long-liv- ing" contaminants, or possible myeloma precursors in the transduced and selected cell fraction, we seeded CD34+/ $\triangle \mathrm{LNGFR}^{+}$cells of patient MM18 in a LTMC assay, adding IL6 to the culture to favour the maintenance of the plasma cells in culture. After 3 weeks, the cells were placed in a CFU-C assay, picked at the end of the culture, and analyzed for specific myeloma rearrangements. $100 \%$ of the colonies (42 out of 42) tested resulted negative for the patient-specific rearrangement (data not shown).

\section{Discussion}

Available clinical evidences suggest that $\mathrm{CD} 34^{+}$selection reduces myeloma contamination in PBSC (Peripheral Blood Stem Cell) collections [5,6,24,25], however, it does not eliminate it, and it does not improve disease-free or overall survival of transplanted patients $[8,9,26]$. We sought to improve the molecular purging of leukaphereses for autografting by exploiting the in-vitro biological behaviour of myeloma cancer cells. The results achieved with our protocol strongly suggest that optimised short-culture conditions provide a major contribution to purging: rearrangement-undetectable CD $34^{+}$cells were generated in $57 \%$ ( 4 out of 7 ) samples. To further improve the purging results, we exposed CD34-selected cells to a retroviral transduction with a selectable membrane-associated marker. This innovative combined procedure exploits the gene transfer technique to enrich for high repopulating-capacity $\mathrm{CD} 34^{+}$cells, and, at the same time, to eliminate myeloma contaminants. Moreover, an 


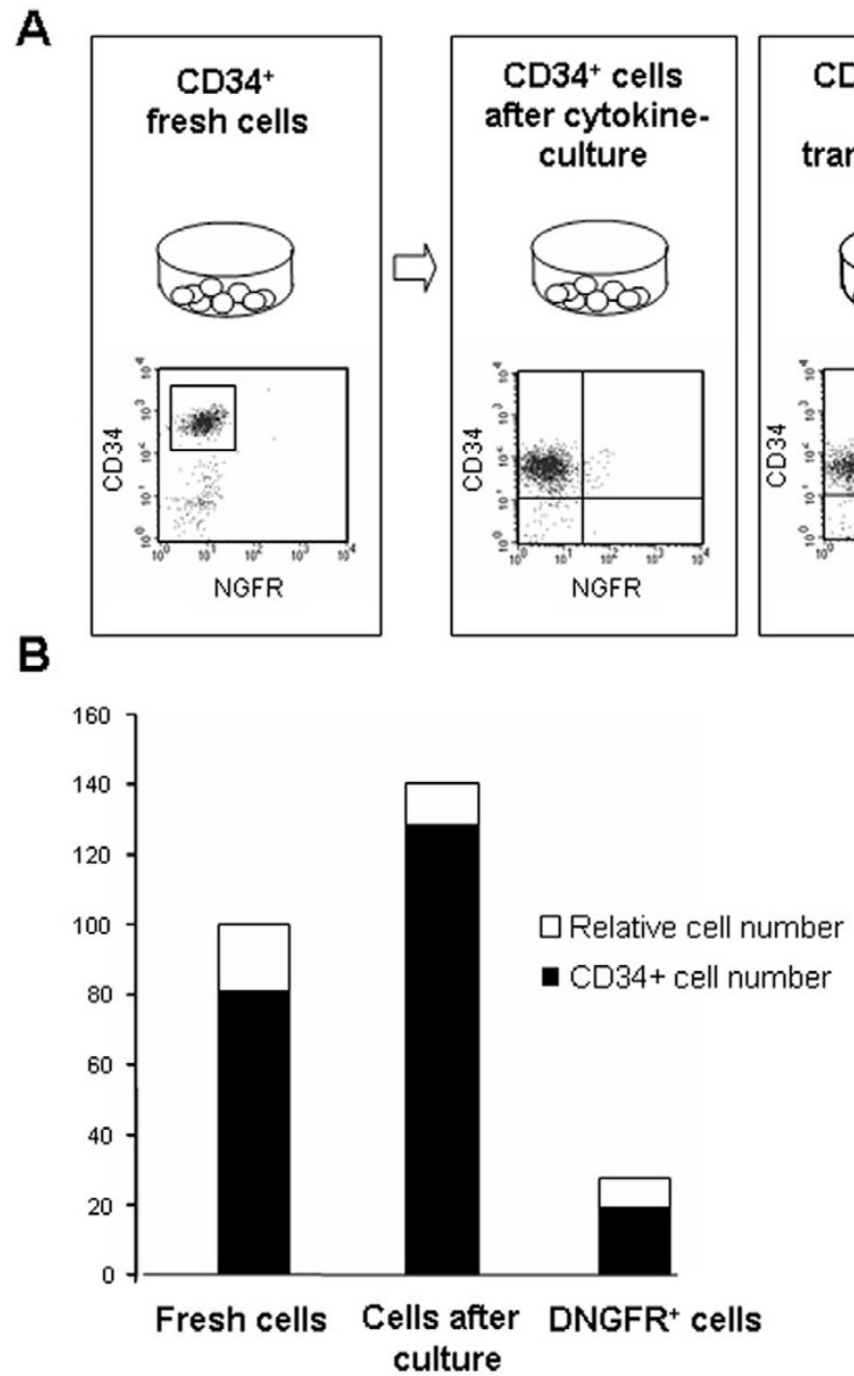

Figure I

MPB CD34+ cells of myeloma patients before and after culture, and transduction. (A) Phenotypic analyses of CD34+ cells before and after cytokine culture, $\triangle$ NGFR transduction, and selection of transduced cells. (B) Relative fold expansion in culture, and recovery after transduction and selection of total cells (open bars) and CD34+ cells (black bars), were measured, in comparison with the initial cell population (fresh cells).

advantage of this approach is that it foresees the outcome of a possible future gene therapy addressed to the CD34+ cells and their progeny.

The transduction and selection results indicate that the procedure is clinically feasible, with a mean amount of $22.3 \pm 15 \%$ final transduced and selected CD $34^{+}$cells, with respect to the initial $\mathrm{CD} 34^{+}$cell number. We have previously demonstrated that $\Delta \mathrm{LNGFR}^{+}$selected CD34+ cells are capable of developing a multilineage reconstitution profile in a relevant animal model [18]. Previous reports have already assessed ex-vivo culture for purging of tumor cells in myeloma and lymphoma $[27,28]$, but the long culture period (7-21 days) render these cells unsuitable for reinfusion.

We could not correlate our purging efficiency with cell expansion, neither with transduction efficiency, nor with cell recovery. The only parameter we could link with a poor purging outcome was the $\triangle$ NGFR purity of selection. Although it occurred in a single sample, a $\triangle$ NGFR purity of $<93 \%$ correlated with the persistency of tumor contamination after culture and selection of transduced cells (see Table 1 and 2). 
Table 2: Results of tumor cell purging in mobilized blood cells before and after serial purging steps

\begin{tabular}{|c|c|c|c|c|}
\hline \multicolumn{5}{|c|}{ Tumor cell frequency } \\
\hline \multicolumn{5}{|l|}{ Log decrease } \\
\hline Exp. & Mobilized blood aphereses & CD34+ selected fresh cells & CD34+ cells after culture & NGFR+ selected cells \\
\hline \multirow[t]{2}{*}{ MM 3} & $<1: 49334$ & $<1: 49334$ & N.D. & $<1: 49334$ \\
\hline & 0 & 0 & - & 0 \\
\hline \multirow[t]{2}{*}{ MM 6\# } & I:2449 & $1: 1179 \mid$ & $<1: 89606$ & $<1: 89606$ \\
\hline & 0 & 0.68 & $>1.56$ & $>1.56$ \\
\hline \multirow[t]{2}{*}{ MM IO } & $>1: 6211$ & $>1: 28818$ & N.D. & I:28852 \\
\hline & 0 & $<0.67$ & - & 0.67 \\
\hline \multirow[t]{2}{*}{ MM I $2^{\#}$} & $1: 4239$ & $<1: 89606$ & $<1: 89606$ & $<1: 89606$ \\
\hline & 0 & $>1.32$ & $>1.32$ & $>1.32$ \\
\hline \multirow{2}{*}{ MM I3\# } & $\mathrm{I}: 10646$ & $<1: 89606$ & $<1: 89606$ & $<1: 89606$ \\
\hline & 0 & $>0.92$ & $>0.92$ & $>0.92$ \\
\hline \multirow[t]{2}{*}{ MM I4\# } & $1: 490$ & I:11162 & $<1: 109697$ & $<1: 109697$ \\
\hline & 0 & 1.36 & $>2.35$ & $>2.35$ \\
\hline \multirow[t]{2}{*}{ MM I5\# } & N.D. & I:12789 & $1: 2669$ & $1: 26667$ \\
\hline & N.D. & 0 & 0 & I \\
\hline \multirow[t]{2}{*}{ MM 16} & N.D. & $>1: 12422$ & $1: 28852$ & $\mathrm{l}: 89256$ \\
\hline & N.D. & 0 & 0.37 & 0.86 \\
\hline \multirow[t]{2}{*}{ MM I8\# } & N.D. & $1: 238$ & $<\mathrm{l}: 44823$ & $<1: 44823$ \\
\hline & N.D. & 0 & $>2.27$ & $>2.27$ \\
\hline \multirow[t]{2}{*}{ MM 19} & N.D. & $\mathrm{I}: 89286$ & $<1: 89606$ & $<1: 89606$ \\
\hline & N.D. & 0 & $>0$ & $>0$ \\
\hline \multirow[t]{2}{*}{ POOLED DATA } & $|: 529|$ & I:12270 & $1: 84602$ & I:208333 \\
\hline & 0 & 0.36 & 1.2 & 1.59 \\
\hline
\end{tabular}

Mobilized blood cells were analyzed after different purging steps for tumor load, where the specific MM marker was available. DNA from I $\times 10^{4}$, or $2 \times 10^{4}$ cells was amplified to detect MM contaminants. For 6 patients $(\#)$ serial dilutions of DNA were performed, with 0.5 logs step dilutions. The quantification of malignant cells in each cell fraction was calculated according to the single-hit Poisson model, and expressed as tumor cell frequency (I:X). The logarithmic decrease (lower part of cells) was calculated with respect to the foregoing unpurged sample indicated with "0". When the frequency of tumor contamination was below the detection threshold of the system, PCR were scored as negative (clear-shaded cells). The pooled data represent frequency determinations, according to the statistical method by Taswell.

NCored as negative

$\triangle \mathrm{NGFR}^{+}$selection appeared to improve the tumor load removal, with respect to the simple culture-based purging. However, we did not observe a complete elimination of residual myeloma contaminants. DNA deriving from dead cells, still present at the end of the procedure, or actual tumor contaminants could explain the incomplete purging. Our experiments show a very low probability for plasma cells to be transduced in these culture conditions. Rather, the involvement of myeloma plasma cells in $\triangle$ LNGFR selection could occur because of their inherent characteristics, leading them to adhere via surface Ig to beads-coated antibodies. Since we did not reach a complete purging in $\triangle \mathrm{LNGFR}^{+}$selected cells, we performed a clonogenic analysis on a $\triangle \mathrm{LNGFR}^{+}$contaminated cell fraction which suggested that the myeloma contaminants present in the final cell fraction do not retain clonogenic capacity.
We previously demonstrated the multilineage reconstitution potential of MPB CD34+ cells treated with the same culture and transduction protocol in SCID-hu animal models [18]. This particular animal model allows the differentiation of lymphocytes in a suitable microenvironment. We showed a maintained lymphoid reconstitution potential, with differentiation of mature $B$ and T cells after CD $34^{+}$cell transplant. We assume that a good and early lymphoid cell reconstitution is necessary in myeloma patients undergoing autologous transplants to protect against post-transplant infections [13], and probably against early tumor relapse. Nevertheless, we acknowledge the need for a more stringent assay of myeloid repopulating capacity, in order to move the technique into clinical application.

Table 3: Statistical comparison of tumor load between different cell populations

\begin{tabular}{|c|c|c|c|c|}
\hline & ESTIMATED DECREASE (RATIO) & $95 \%$ CONFIDENCE & INTERVAL & P VALUE \\
\hline CD $34^{+}$fresh cells versus $C D 34^{+}$cells after culture & 6.86 & 1.75 & 27.17 & $5.78 \times 10^{-3}$ \\
\hline CD34+ fresh cells versus $\Delta \mathrm{NGFR}^{+}$selected cells & 16.98 & 5.54 & 52.04 & $8.29 \times 10^{-7}$ \\
\hline${\text { CD } 34^{+}}^{+}$after culture versus $\Delta \mathbf{N G F R}^{+}$selected cells & 2.46 & 0.43 & 14.15 & $3.12 \times 10^{-1}$ \\
\hline
\end{tabular}

The amount of purging was evaluated in different coupled cell populations, and expressed as ratio of contaminant tumor cells (number of tumor cells pre purging/number of tumor cells after purging). 

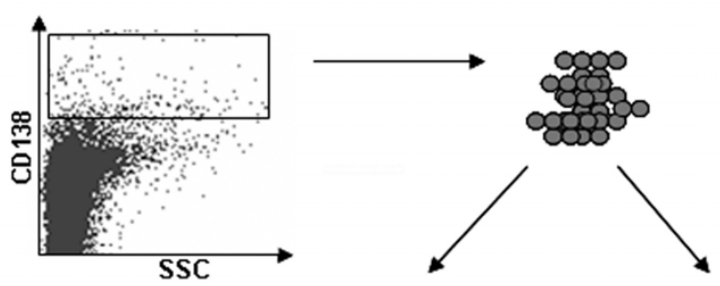

A $\mathrm{CD} 138^{+} / \mathrm{CD}^{+} 4^{+}$ bulk transduction
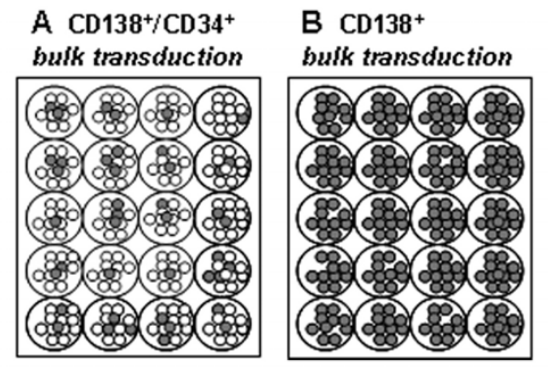

C CD138 $^{+}$

clonal transduction

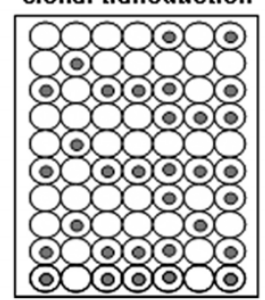

Figure 2

Transduction pattern of myeloma plasma cells. CDI38+ selected myeloma bone marrow plasma cells were transduced with the $\triangle N G F R$ vector in a bulk, and in a clonal culture (B and $C)$. Part of the cells was mixed before transduction with CD34+ cells of the same patient (A). Culture conditions were the same as in the CD34+ cell transductions.

Recently, several clinical leukemia events reported by Hacein-Bey-Abina et al. in severe combined immunodeficiency-X linked (SCID-X) patients treated with $\gamma$-chain transduced CD34+ cells [29] raised questions about the general safety of retrovirus-based gene therapy. The issue is still under intensive investigation with extensive analyses performed on transduced cells [30]. So far, no other group has reported similar adverse events, despite a high number of clinical trials performed in more than 10 years of gene therapy and gene marking studies [31]. Still, a justified caution in evaluating risks and benefits of a gene therapy clinical procedure is now mandatory.

Among the performed sequential purging steps, the CD34 selection was the least efficient: we could also consider applying the culture protocol directly to the whole leukapheresis. Provided that we reach experimental evidences of a similar purging, this setting would simplify the cell manipulation process and render the procedure more suitable for a clinical application.

\section{Conclusion}

We conclude that the culture purging approach we have devised could be a feasible and efficient procedure for MM patients undergoing autologous transplantation. There is also a tendency of myeloma contaminants to further decrease after transduction and selection of CD34+ cells, as compared with the simple culture. An advantage of the transduction protocol is a potentially myeloma-free population of marked cells, detectable over time. Gene marking of autografted cells has been shown to be a valuable tool to trace long-term reconstitution of the host [32], and the origin of disease relapse [33]. A pilot study for MM patients eligible to high dose chemotherapy and autologous transplant would clarify the effectiveness of the purging transplant approach described in this work. The safe reconstitution capacity of $\mathrm{CD}_{3} 4^{+}$transduced cells could also allow a future gene therapy trial directed to hematopoietic CD34+ cells.

\section{Abbreviations}

$\triangle$ NGFR: truncated form of the human Nerve Growth Factor Receptor

\section{BM: Bone Marrow}

CFU-C: Colony Forming Units-Cells

CI: Confidence Interval

GvHD: Graft versus Host Disease

IgH: Immunoglobulin Heavy chain

IL: Interleukin

LTMC: Long-Term Marrow Cultures

MC: Method of likelihood maximization and $\chi^{2}$ minimization

MM: Multiple Myeloma

MoMLV: Moloney Murine Leukemia Virus

MPB: Mobilized Peripheral Blood

PBSC: Peripheral Blood Stem Cell

SCID-hu: Severe Combined Immunodeficiency-humanized

SCID-X: Severe Combined Immunodeficiency-X linked

SN: Viral Supernatant

\section{Declaration of competing interests}

The author(s) declare that they have no competing interests.

\section{Authors' contributions}

SD performed experiments, analyses and wrote the paper. 
SS, RSC, MC, FF, JD performed cell culture experiments and analyses.

$\mathrm{CV}$ and $\mathrm{MM}$ created the patient specific sequences, and analysed the molecular purging data

SV performed statistical analyses.

EP, GC, JP, CB, MGR and AA participated in the study design.

$\mathrm{MB}$ conceived the study, coordinated the work, and helped in writing the paper.

\section{All authors read and approved the final manuscript.}

\section{Acknowledgements}

We thank Chiara Villa and Vittorio Perfetti for the work performed on patient-specific tumor rearrangements, Juan A Bueren and Guillermo Guenechea for help with animal experiments, and Paolo Corradini for helpful discussions. We also thank Giovanna Scarel for careful revision of the manuscript.

Supported in part by a grant from Consiglio Nazionale Ricerche and from Associazione Italiana per la Ricerca sul Cancro to $M B$, and by a grant from FIRB, Ministero dell'Università e Ricerca Scientifica, to AA.

\section{References}

I. Fermand JP, Ravaud P, Chevret S, Divine M, Leblond V, Belanger C, Macro M, Pertuiset E, Dreyfus F, Mariette X, Boccacio C, Brouet JC: High-Dose Therapy and Autologous Peripheral Blood Stem Cell Transplantation in Multiple Myeloma: Up-front or Rescue Treatment? Results of a Multicenter Sequential Randomized Clinical Trial. Blood 1998, 92:3131-3136.

2. Child JA, Morgan GJ, Davies FE, Owen RG, Bell SE, Hawkins K, Brown J, Drayson MT, Selby PJ, Medical Research Council Adult Leukaemia Working Party: High-dose chemotherapy with hematopoietic stem-cell rescue for multiple myeloma. N Engl J Med 2003, 348: $1875-83$.

3. Attal M, Harousseau JL, Facon T, Guilhot F, Doyen C, Fuzibet JG, Monconduit M, Hulin C, Caillot D, Bouabdallah R, Voillat L, Sotto J, Grosbois B, Bataille R, InterGroupe Francophone du Myelome: Single versus double autologous stem-cell transplantation for multiple myeloma. N Engl J Med 2003, 349:2495-502.

4. Schiller G, Vescio R, Freytes C, Spitzer G, Sahebi F, Lee M, Wu CH, Cao J, Lee JC, Hong CH, Lichtenstein A, Lill M, Hall J, Berenson R, Berenson J: Transplantation of CD34+ peripheral blood progenitor cells after high-dose chemoterapy for patients with advanced multiple myeloma. Blood 1995, 86:390-397.

5. Lemoli RM, Fortuna A, Motta MR, Rizzi S, Giudice V, Nannetti A, Martinelli G, Cavo M, Amabile M, Mangianti S, Fogli M, Conte R, Tura S: Concomitant mobilization of plasma cells and hematopoietic progenitors into peripheral blood of multiple myelma patients: positive selection and transplantation of enriched CD34+ cells to remove circulating tumor cells. Blood 1996, 87:1625-1634

6. Vogel W, Kopp HG, Kanz L, Einsele H: Myeloma cell contamination of peripheral blood stem-cell grafts can predict the outcome in multiple myeloma patients after high-dose chemotherapy and autologous stem-cell transplantation. J Cancer Res Clin Oncol 2005, I 3 I (4):2 I 4-8.

7. Gertz MA, Witzig TE, Pineda AA, Greipp PR, Kyle RA, Litzow MR: Monoclonal plasma cell in the blood stem cell harvest from patients with multiple myeloma are associated with shortened relapse free survival after transplantation. Bone marrow Transplant 1997, 19:337-342.
8. Stewart AK, Vescio R, Schiller G, Ballester O, Noga S, Rugo H, Freytes C, Stadtmauer E, Tarantolo S, Sahebi F, Stiff P, Meharchard J, Schlossman R, Brown R, Tully H, Benyunes M, Jacobs C, Berenson R, White M, DiPersio J, Anderson KC, Berenson J: Purging of autologous peripheral-blood stem cells using CD34 selection does not improve overall or progression-free survival after highdose chemotherapy for multiple myeloma: results of a multicenter randomized controlled trial. J Clin Oncol 200I, I 9:377|-3779.

9. Lemoli RM, Martinelli G, Zamagni E, Motta MR, Rizzi S, Terragna C, Rondelli R, Ronconi S, Curti A, Bonifazi F, Tura S, Cavo M: Engraftment, clinical, and molecular follow-up of patients with multiple myeloma who were reinfused with highly purified CD34+ cells to support single or tandem high-dose chemoterapy. Blood 2000, 95:2234-2239.

10. Gazitt Y, Reading CC, Hoffman R, Wickrema A, Vesole DH, Jagannath S, Condino J, Lee B, Barlogie B, Tricot G: Purified CD34+Lin-Thy+ stem cells do not contain clonal myeloma cells. Blood 1995 , 86:381-389.

II. Michallet M, Philip T, Philip I, Godinot H, Sebban C, Salles G, Thiebaut A, Biron P, Lopez F, Mazars P, Roubi N, Leemhuis T, Hanania E, Reading C, Fine G, Atkinson K, Juttner C, Coiffier B, Fiere D, Archimbaud $E:$ Transplantation with selected autologous peripheral blood CD34+Thy+ hematopoietic stem cells (HSCs) in multiple myeloma: impact of HSC dose on engraftment, safety, and immune reconstitution. Exp Hematol 2000, 28:858-870.

12. Altes A, Sierra J, Esteve J, Martin-Henao G, Marin P, Sureda A, Briones J, Martino R, Villamor N, Colomer D, Carreras E, Garcia J, Brunet S, Montserrat E: CD34+-enriched-CD I9+-depleted autologous peripheral blood stem cell transplantation for chronic lymphoproliferative disorders: high purging efficiency but increased risk of severe infections. Exp Hematol 2002, 30:824-830.

13. Barbui AM, Galli M, Dotti G, Belli N, Borleri G, Gritti G, Bellavita P, Viero P, Comotti B, Barbui T, Rambaldi A: Negative selection of peripheral blood stem cells to support a tandem autologous transplantation programme in multiple myeloma. $\mathrm{Br} J \mathrm{Hae}-$ matol 2002, I | 6:202-210.

14. De Vos J, Bagnis C, Bonnafoux L, Requirand G, Jourdan M, Imbert MC, Jourdan E, Rossi JF, Mannoni P, Klein B: Comparison of murine leukemia virus, human immunodeficiency virus, and adeno-associated virus vectors for gene transfer in multiple myeloma: lentiviral vectors demonstrate a striking capacity to transduce low-proliferating primary tumor cells. Hum Gene Ther 2003, I 4: 1727-1739.

15. Björkstrand B, Dilber MS, Smith CIE, Gahrton G, Xanthopoulos KG: Retroviral-mediated gene transfer into myeloma cells. Brit J Haematol 1994, 88:325-331.

16. Bordignon C, Bonini C: A clinical protocol for gene transfer into peripheral blood lymphocytes for in vivo immunomodulation of donor anti-tumor immunity in patients affected by recurrent disease after allogeneic bone marrow transplantation. Hum Gen Ther 1995, 2:813-819.

17. Bonini C, Ferrari G, Verzeletti S, Servida P, Zappone E, Ruggieri L, Ponzoni M, Rossini S, Mavilio F, Traversari C, Bordignon C: HSV-TK gene transfer into donor lymphocytes for control of allogeneic graft-versus-leukemia. Science 1997, 276: I7I9-I724.

18. Deola S, Scaramuzza S, Birolo RS, Carballido-Perrig N, Ficara F, Mocchetti C, Dando J, Carballido JM, Bordignon C, Roncarolo MG, Bregni M, Aiuti A: Mobilized blood $C D 34^{+}$cells transduced and selected with a clinically applicable protocol reconstitute lymphopoiesis in SCID-Hu mice. Hum Gene Ther 2004, I5:305-3 II.

19. Dando JS, Aiuti A, Deola S, Ficara F, Bordignon C: Optimisation of retroviral supernatant production conditions for the genetic modification of human CD34+ cells. J Gene Med 2001, 3:219-227.

20. Stewart AK, Prince HM, Cappe D, Chu P, Lutzko C, Sutherland DR, Dube ID: In vitro maintenance and retroviral transduction of human myeloma cells in long-term marrow cultures. Cancer Gene Ther 1997, 4:148-I56.

21. Voena C, Ladetto M, Astolfi M, Provan D, Gribben JG, Boccadoro M, Pileri A, Corradini P: A novel nested-PCR strategy for the detection of rarranged immunoglobulin heavy-chain genes in B cell tumors. Leukemia 1997, I:1793-1798. 
22. Taswell C: Limiting dilution assays for the determination of immunocompetent cell frequencies. I. Data analysis. J Immunol 1981, I26:1614-1619.

23. Deola S, Bregni M, Ficara F, Dando J, Bordignon C, Aiuti A: Efficient ex-vivo immunoselection of $\Delta$ NGFR-transduced mobilized CD34+ cells [abstract]. Haematologica 1999, 84:124.

24. Rasmussen $T$, Bjorkstrand B, Andersen H, Gaarsdal E, Johnsen HE: Efficacy and safety of CD34-selected and CDI9-depleted autografting in multiple myeloma patients: a pilot study. Exp Hematol 2002, 30:82-88

25. Tricot G, Gazitt $Y$, Leemhuis T, Jagannath S, Desikan KR, Siegel D, Fassas A, Tindle S, Nelson J, Juttner C, Tsukamoto A, Hallagan J, Atkinson K, Reading C, Hoffman R, Barlogie B: Collection, tumor contamination, and engraftment kinetics of highly purified hematopoietic progenitor cells to support high dose therapy in multiple myeloma. Blood 1998, $91: 4489-4495$.

26. Kumar A, Loughran T, Alsina M, Durie BGM, Djulbegovic B: Management of multiple myeloma: a systemic review and critical appraisal of published studies. Lancet 2003, 4:293-304.

27. Van Riet I, Juge-Morineau N, Schots R, De Waele M, De Greef C, Thielemans K, Van Camp B, Bakkus M: Persistence of residual tumour cells after cytokine-mediated ex vivo expansion of mobilized CD34+ blood cells in multiple myeloma. Br J Haematol 1997, 96:403-II.

28. Widmer L, Pichert G, Jost LM, Stahel RA: Fate of contaminating $t(I 4 ; 18)+$ lymphoma cells during ex vivo expansion of CD34selected hematopoietic progenitor cells. Blood 1996, 88:3166-75.

29. Hacein-Bey-Abina S, Von Kalle C, Schmidt M, McCormack MP, Wulffraat N, Leboulch P, Lim A, Osborne CS, Pawliuk R, Morillon E, Sorensen R, Forster A, Fraser P, Cohen II, de Saint Basile G, Alexander I, Wintergerst U, Frebourg T, Aurias A, Stoppa-Lyonnet D, Romana S, Radford-Weiss I, Gross F, Valensi F, Delabesse E, Macintyre E, Sigaux F, Soulier J, Leiva LE, Wissler M, et al.: LMO2-associated clonal $T$ cell proliferation in two patients after gene therapy for SCID-XI. Science 2003, 302:415-9.

30. Thrasher AJ, Gaspar HB, Baum C, Modlich U, Schambach A, Candotti F, Otsu M, Sorrentino B, Scobie L, Cameron E, Blyth K, Neil J, Abina SH, Cavazzana-Calvo M, Fischer A: Gene therapy: X-SCID transgene leukaemogenicity. Nature 2006, 443(7 I09): I I 23.

31. Bonini C, Grez M, Traversari C, Ciceri F, Marktel S, Ferrari G, Dinauer M, Sadat M, Aiuti A, Deola S, Radrizzani M, Hagenbeek A, Apperley J, Ebeling S, Martens A, Kolb HJ, Weber M, Lotti F, Grande A Weissinger E, Bueren JA, Lamana M, Falkenburg JH, Heemskerk MH, Austin T, Kornblau S, Marini F, Benati C, Magnani Z, Cazzaniga S, et al.: Safety of retroviral gene marking with a truncated NGF receptor. Nat Med 2003, 9:367-9.

32. Brenner MK, Rill DR, Holladay MS, Heslop HE, Moen RC, Buschle M, Krance RA, Santana VM, Anderson WF, Ihle JN: Gene marking to determine whether autologous marrow infusion restores long-term haemopoiesis in cancer patients. Lancet 1993, 342: II34-7.

33. Brenner MK, Rill DR, Moen RC, Krance RA, Mirro J Jr, Anderson WF, Ihle JN: Gene-marking to trace origin of relapse after autologous bone-marrow transplantation. Lancet 1993, 341:85-6. http://www.translational-medicine.com/content/5/1/35

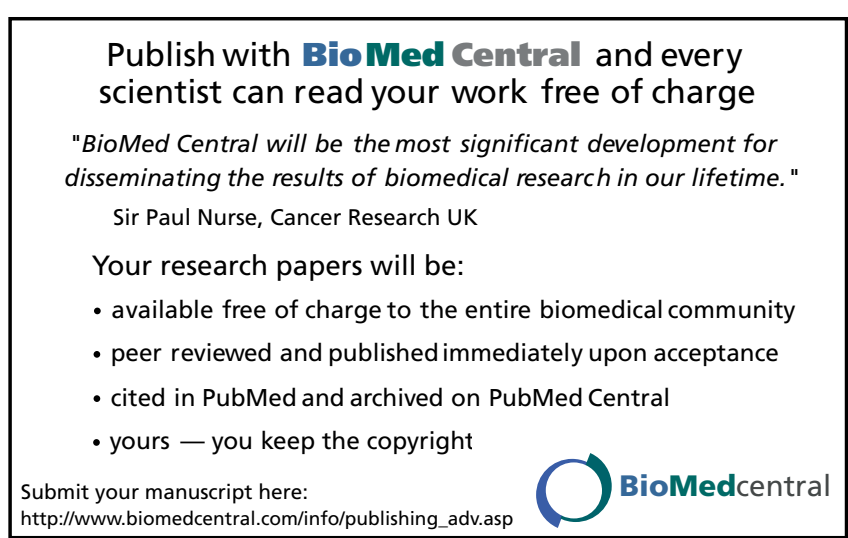

